\title{
Impact of feline zona pellucida glycoprotein B-derived synthetic peptides on in vitro fertilization of cat oocytes
}

\author{
Jennifer Ringleb, Marlies Rohleder and Katarina Jewgenow \\ Institute for Zoo and Wildlife Research, PF 601103, D-10252 Berlin, Germany \\ Correspondence should be addressed to J Ringleb; Email: ringleb@izw-berlin.de
}

\begin{abstract}
Although immunocontraception based on porcine zona pellucida (ZP) proteins is widely applied in many species, it is not suitable for cat contraception due to the lack of cross-reactivity. Since the first ZP gene expressed during oocyte growth in domestic cats is ZPB, we assumed that immunization with feline ZPB (fZPB)-derived synthetic peptides may cause irreversible infertility, which would be preferable in stray cats. Thus, the present study evaluated the immunogenicity and the contraceptive potential of synthetic fZPB peptides. Antigenic epitope sequences were detected via epitope mapping using specific rabbit anti-fZP antibodies. Six peptides representing the recognized epitopes were synthesized subsequently. Two out of six peptides (ZPB amino acid residue 130-149 = P3 and 175-193 = P6) cross-reacted with anti-fZP antiserum in dot blot analysis and ELISA. Coupled to BSA, both peptides were utilized to produce specific antibodies in rats. Despite several booster injections the antibody titers monitored by ELISA did not exceed 1:5000. Both rat antisera were tested for contraceptive potential in cat in vitro maturation/in vitro fertilization (IVF). Antiserum against peptide P3 significantly inhibited sperm binding and fertilization of cat oocytes in vitro $(\mathbf{5 7 . 3} \%$ of sperm binding; $\mathbf{4 1 . 5 \%}$ of fertilization), whereas the inhibition by anti-P6 was not significant. Pre-incubation of sperm cells with both peptides before IVF failed to affect either sperm binding or fertilization (22.3 \pm 3.7 sperm/egg vs $25.5 \pm 5.8$ for $\mathrm{P} 3$ and $20.7 \pm 4.0$ for $\mathrm{P} 6$, respectively). In conclusion, antibodies directed against one of the two identified antigenic determinants of IZPB inhibited sperm binding and IVF and therefore showed promising results as a contraceptive. However, the specific immune response and anti-fertile properties of this synthetic vaccine have to be examined in vivo to verify the suitability of its components.

Reproduction (2004) 127 179-186
\end{abstract}

\section{Introduction}

Developing an approach to control feral cat populations in urban regions remains an unsolved problem. To reduce reproduction, so called 'trap-neuter-and-release' programs are performed with some success (Foley et al. 2002). However, capturing cats with traps, transportation to veterinary clinics, and surgical castration is time-consuming, stressful for the animal and associated with high costs (Asa et al. 1996). Therefore, there is an increasing requirement for alternative methods for the control of reproduction in feral cats.

Since immunocontraception with zona pellucida (ZP) proteins was shown to be effective in feral and wildlife animals (Sacco et al. 1989, Kirkpatrick et al. 1993), the use of ZP immunization has been considered as an alternative approach for cats (Ivanova et al. 1995, Barber et al. 2001, Gorman et al. 2002). The ZP is an acellular glycoprotein layer surrounding the mammalian egg and plays a fundamental role in sperm-egg interaction. Active immunization against ZP proteins inhibits fertility in many species by interfering with sperm-egg interaction during fertilization, and affecting the growing pool of ovarian follicles. The synthesis of ZP takes place during oocyte growth. Therefore, a cellular immune reaction against ZP can induce reduction or destruction of early ovarian oocytes (Skinner et al. 1984, Mahi-Brown et al. 1988, Sacco et al. 1991), leading sometimes to irreversible infertility.

Most studies on immunocontraception of feral and wildlife animals apply porcine ZP (pZP), due to its interspecific cross-reactivity in many species and the easy availability of pig ovaries from slaughterhouses. In cats, however, pZP is not applicable, because of missing cross-reactivity to feline ZP (fZP) proteins (Jewgenow et al. 2000, Gorman et al. 2002). Using native fZP proteins for contraception, however, is not possible because of the limited availability of the source material.

To develop a fZP-based contraceptive vaccine for cat contraception, we planned to identify immunologically 
relevant epitopes of $\mathrm{fZP}$, and to test the amino acid sequence of these epitopes for their contraceptive potential in cats by using in vitro fertilization (IVF) protocols.

The ZP of cats is composed of three proteins, which are encoded in the DNA sequences fZPA, fZPB and fZPC (Harris et al. 1994). Based on our previous studies, we used the sequence of $\mathrm{FZPB}$ for epitope mapping, since fZPB is the first ZP that is synthesized during cat oogenesis (Jewgenow \& Fickel 1999). We hypothesized that an immune response against fZPB increases the possibility of permanent contraception - a desirable result for feral cats - by destruction of intra-ovarian oocytes.

The immunogenic epitopes of the fZPB-derived amino acid sequence were identified by the spot synthesis technique (Frank 1992) using a highly specific antiserum against fZP (Jewgenow et al. 2000). Then, the peptides representing these epitopes were synthesized and tested for their ability to interfere with fertilization of cat oocytes in vitro.

\section{Materials and Methods}

All chemicals were obtained from Sigma-Aldrich $\mathrm{GmbH}$ (Steinheim, Germany) unless stated otherwise and were of the highest purity available.

Polyclonal antibodies against native fZP and pZP were obtained by immunization of rabbits as previously described (Jewgenow et al. 2000). The high specificity of these antibodies for native zona proteins was shown by ELISA, immunoelectrophoresis and immunohistology. Their anti-fertile effect has been demonstrated in vitro by inhibition of sperm binding and fertilization.

\section{Epitope mapping of $f Z P B$}

Scans of 187 overlapping peptides (PepScans; Jerini BioTools $\mathrm{GmbH}$, Berlin, Germany) comprising the entire amino acid sequence of fZPB (Harris et al. 1994) were used to map linear binding sites. Using the primary sequence, 13-mers that overlap in sequence by ten amino acids were synthesized on cellulose membrane (Whatman, Maidstone, Kent, UK). Spot synthesis technique was described in detail by Reineke et al. (1999) and Frank (1992) and was carried out by Jerini BioTools GmbH.

Before use, the membrane was rinsed in $96 \%(\mathrm{v} / \mathrm{v})$ ethanol (1 $\mathrm{min})$, washed three times in Tris-buffered saline (TBS) $(50 \mathrm{mmol} / \mathrm{l}$ Tris, $137 \mathrm{mmol} / \mathrm{l} \mathrm{NaCl}, 2.7 \mathrm{mmol} / \mathrm{l} \mathrm{KCl}$, $\mathrm{pH} 8.0,10 \mathrm{~min}$ ) and blocked overnight in TBS with $0.5 \%$ skimmed milk powder (Oxoid Unipath Ltd, Basingstoke, Hants, UK) and $0.05 \%$ Tween 20. After three washes in TBS $+0.05 \%$ Tween $20(10 \mathrm{~min})$ the membrane was incubated with anti-fZP antiserum $(1: 1000)$ for $3 \mathrm{~h}$. Unbound antibodies were removed by repeated washing in TBS + Tween 20, before the secondary antibody, peroxidase (POD)-labeled anti-rabbit IgG, was added at a dilution of 1:2000. After incubation for $1 \mathrm{~h}$ and washing in TBS + Tween $(3 \times 10 \mathrm{~min})$, detection of epitopes was performed by chemiluminescence with ECL Western Blotting Detection Reagents (Amersham Life Science, Little Chalfont, Bucks, UK) according to the maker's manual. A high performance chemiluminescence film (Amersham Life Science) was placed directly onto the membrane and exposed in Hypercassettes (Amersham Life Science) for $1-2 \min$.

At least three or four dots in line were considered to be an epitope. Identified sequences were checked for the level of antigenicity by the algorithm of Hopp \& Woods (1981). The program was obtained via the Internet (www.emblheidelberg.de/JaBMW/3/1/7/). Based on these results the sequences were partially reduced or extended by a few amino acids. Finally, peptides representing the ultimate sequences were synthesized by Jerini BioTools $\mathrm{GmbH}$.

\section{Estimation of cross-reactivity with antisera against $f Z P$}

Cross-reactivity with fZP antisera of synthetic peptides dissolved in phosphate buffered saline (PBS; $1.62 \mathrm{mmol} / \mathrm{l}$ $\mathrm{Na}_{2} \mathrm{HPO}_{4}, 0.027 \mathrm{mmol} / \mathrm{l} \mathrm{NaCl}, 0.54 \mathrm{mmol} / \mathrm{l} \mathrm{KCl}, 0.3 \mathrm{mmol} / \mathrm{l}$ $\mathrm{KH}_{2} \mathrm{PO}_{4}$ ) was checked using dot immunoassay and ELISA.

For dot immunoassay, aliquots of $2-5 \mu$ l peptide solution $(1 \mathrm{mg} / \mathrm{ml}$ peptide in PBS) were transferred to Hybond ECL Nitrocellulose (Amersham Life Science), and airdried. Then, the membrane was blocked (for $6 \mathrm{~h}$ ) and coincubated with antiserum (16 h) and secondary antibodies $(1 \mathrm{~h})$ in the same manner as described for epitope mapping (see above). The binding of the antiserum was assessed by chemiluminescence. The strength of the immune reaction was determined by the darkness of the spots ranging from shades of gray to black.

For ELISA, 96-well microtiter plates were coated with $1 \mu \mathrm{g}$ peptide/well diluted in $100 \mu \mathrm{l}$ coating buffer (0.015 mol/l $\mathrm{Na}_{2} \mathrm{CO}_{3} \cdot 10 \mathrm{H}_{2} \mathrm{O}, 0.03 \mathrm{~mol} / \mathrm{l} \mathrm{NaHCO}_{3}, \mathrm{pH}$ 9.6). Plates were incubated overnight. Unbound peptide was removed and wells were covered with assay buffer (0.04 mol/l Na $\mathrm{HPO}_{4} \cdot 2 \mathrm{H}_{2} \mathrm{O}, 0.15 \mathrm{~mol} / \mathrm{l} \mathrm{NaCl}, 0.1 \%$ (w/v) $\mathrm{BSA})$ for $30 \mathrm{~min}$ at room temperature. Increasing dilutions of specific anti-fZP antiserum (1:2500-1:160000) were pipetted into each well. After incubation overnight at $4{ }^{\circ} \mathrm{C}$ and washing, POD-labeled anti-rabbit IgG (1:10 000) was added for $1 \mathrm{~h}$ at room temperature. The amount of peroxidase retained in the immunocomplex after washing was determined photometrically at $450 \mathrm{~nm}$ with an enzyme substrate solution containing tetramethylbenzidine (Roche Diagnostics GmbH, Mannheim, Germany).

\section{Immunization of rats}

For immunization, the synthetic peptides were coupled to BSA using carbodiimide (Kyrein 1983). Wistar rats were immunized with $250 \mu \mathrm{g}$ peptide-BSA dissolved in $100 \mu \mathrm{l}$ PBS emulsified in $100 \mu \mathrm{l}$ Freund's complete adjuvant for primary injection and incomplete Freund's adjuvant for booster injections. The immunization was performed by Biopharm GmbH (Berlin, Germany). Rats were boosted every 3 weeks for up to seven times with $125 \mu \mathrm{g}$ 
peptide-BSA. Serum samples were collected 10 days after booster injections. Antibody titers of serum samples were determined by ELISA as described above by using peptide-coated plates and several dilutions of rat sera and POD-labeled anti-rat IgG.

After seven immunizations the antibody titers against the peptides did not exceed 1:5000. Due to the low titer, the detection level of peptide antibodies in the dot immunoassay was quite unstable whereas the rat serum always showed strong reaction to the BSA carrier protein, indicating a markedly higher level of anti-BSA antibodies.

\section{In vitro test for sperm binding and fertilization}

Gonads from female and male domestic cats were obtained from the veterinary clinic at the animal shelter house of the City of Berlin. Immediately upon excision, ovaries were placed into Dulbecco's PBS (DPBS) containing $1 \%(\mathrm{v} / \mathrm{v})$ antibiotic and antimycotic solution and were processed within $6 \mathrm{~h}$ on the same day. Testes were stored without any medium and processed the following day. Until processing the gonads were stored at $4{ }^{\circ} \mathrm{C}$.

The in vitro maturation (IVM) and IVF of cat oocytes was performed as described by Freistedt et al. (2001) with small modifications. In brief, ovaries were dissected in M199 containing Earle's salts, supplemented with $3 \mathrm{mg} / \mathrm{ml}$ BSA, $0.6 \mathrm{mg} / \mathrm{ml}$ sodium lactate, $1.4 \mathrm{mg} / \mathrm{ml}$ Hepes, $0.25 \mathrm{mg} / \mathrm{ml}$ sodium pyruvate, $0.1 \mathrm{mg} / \mathrm{ml}$ cysteine and $0.055 \mathrm{mg} / \mathrm{ml}$ gentamicin. Only eggs with complete compact cumulus and uniform, dark cytoplasm were selected, washed three times and transferred into $400 \mu \mathrm{l}$ medium supplemented with $0.02 \mathrm{IU} / \mathrm{ml}$ porcine follicle-stimulating hormone and $0.01 \mathrm{lU} / \mathrm{ml}$ equine luteinizing hormone. Eggs were cultured for $24 \mathrm{~h}$ in a $39{ }^{\circ} \mathrm{C}$ humidified incubator containing $5 \%$ $\mathrm{CO}_{2}$ in air. Additionally, completely denuded oocytes with dark cytoplasm were collected and stored in DPBS overnight at $4{ }^{\circ} \mathrm{C}$. All incubation and washing steps were performed in four-well NUNC (Roskilde, Denmark) dishes and under mineral oil.

Cat spermatozoa were obtained from caudae epididymides by mincing them in $1 \mathrm{ml}$ TALP medium (Tyrode's salt solution containing $6 \mathrm{mg} / \mathrm{ml}$ BSA, $1.2 \mathrm{mg} / \mathrm{ml}$ Hepes, $1.1 \mathrm{mg} / \mathrm{ml}$ sodium lactate, $0.11 \mathrm{mg} / \mathrm{ml}$ sodium pyruvate). Sperm cells were centrifuged at $500 \mathrm{~g}$ for $7 \mathrm{~min}$ and resuspended in 100-200 $\mu$ l TALP medium. After estimation of sperm concentration and motility, a final concentration of $1 \times 10^{5}$ motile sperm cells/ml was established by addition of TALP medium.

In the case of non-availability of fresh testes, cryopreserved sperm cells were thawed for insemination (21 of 51 trials). The sperm cells were frozen using the method described by Lengwinat \& Blottner (1994). Before insemination, $300 \mu \mathrm{l}$ frozen cat sperm were thawed in $37^{\circ} \mathrm{C}$ water for $1.5 \mathrm{~min}$ and diluted with $100 \mu \mathrm{l}$ TALP medium. After determining motility, the concentration was adjusted to $1 \times 10^{6}$ motile spermatozoa $/ \mathrm{ml}$.
The insemination of cat oocytes was performed in $400 \mu$ l of IVF medium (TALP solution containing $10 \mu \mathrm{g} / \mathrm{ml}$ heparin). Then, both in vitro-matured and denuded oocytes were placed into separate insemination drops containing $1 \times 10^{5}$ motile spermatozoa/ml or $1 \times 10^{6}$ for cryopreserved sperm. After $18-20 \mathrm{~h}$ of co-incubation at $39^{\circ} \mathrm{C}$ in an atmosphere of $5 \% \mathrm{CO}_{2}$, the in vitro-matured oocytes were washed three times and cultured in $400 \mu \mathrm{l}$ synthetic oviductal fluid medium (Steeves \& Gardner 1999) for a further $24 \mathrm{~h}$. Denuded oocytes were fixed immediately.

The oocytes were washed three times in DPBS with $3 \mathrm{mg} / \mathrm{ml}$ BSA to remove loosely attached spermatozoa and finally placed into DPBS supplemented with $4 \%$ (w/v) paraformaldehyde and $0.02 \%$ (v/v) Triton-X100 for $45-60 \mathrm{~min}$ at $39{ }^{\circ} \mathrm{C}$. After washing twice again, oocytes were stained with $10 \mu \mathrm{g} / \mathrm{ml}$ Hoechst 33258 for $45 \mathrm{~min}$, mounted on slides and evaluated for attached spermatozoa under fluorescence excitation using a DMLB Leica Microscope (Wetzlar, Germany). Additionally, the in vitro-matured and fertilized oocytes were assessed for chromosomal structures to evaluate the maturation and embryonic stage by aceto-orcein staining. The occurrence of pronuclei and two or more blastomeres were judged as signs of successful IVF.

To test the contraceptive potential of synthetic peptides, two separate experiments for IVM/IVF were performed. In experiment 1 , sperm cells were pre-incubated $1 \mathrm{~h}$ before insemination in peptide solution $(1 \mu \mathrm{g} / \mathrm{ml})$. In experiment 2 , the rat antibodies raised against the peptides were added directly to the fertilization medium at a dilution of $1: 10$. The protein concentration of BSA was diminished to $2.22 \mathrm{mg} / \mathrm{ml}$ accordingly. Adding rat pre-immune serum to the medium served as control.

\section{Statistical analysis}

The data on sperm binding are presented as means \pm S.E.M. Data were tested for normal distribution. In all data sets this was the case. Differences between treatment groups were assessed by the non-parametric Mann-Whitney test.

Maturation and fertilization rates were the outcomes of several weeks of experiments. Control and treatment groups were compared with chi-square tests using $2 \times 2$ tables. $P$ values $<0.05$ were considered to be significantly different. The statistical procedures were performed with the software program Instat Version 3 (GraphPad Software Inc., San Diego, CA, USA).

\section{Results}

\section{Epitope mapping and cross-reactivity of synthetic peptides with antisera against $f Z P$ and $p Z P$}

Six epitopes were identified by epitope mapping of fZPB protein (Figs 1 and 2, Table 1). All epitope-based synthetic 


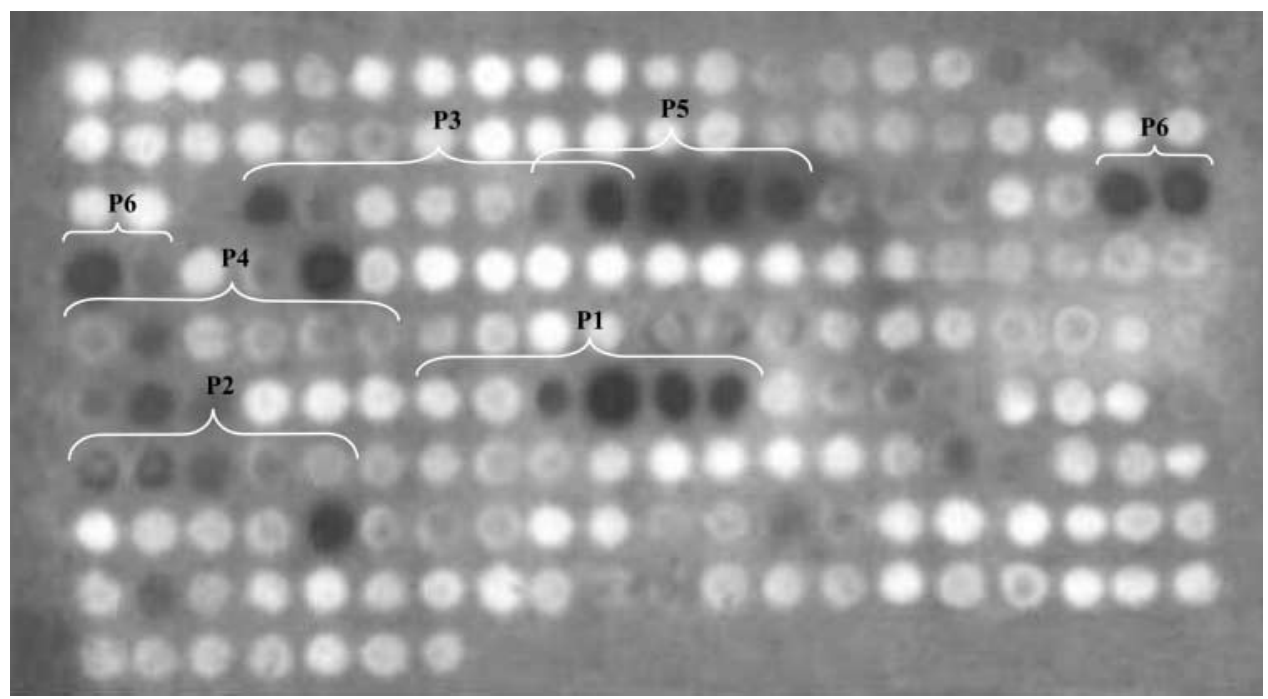

Figure 1 Epitope mapping of fZPB: immune reaction of anti-fZP antiserum against synthesized overlapping peptides comprising the entire amino acid sequence of fZPB (Harris et al. 1994). The brackets indicate the location of the chosen peptides P1-P6. Due to the variability of spot-staining intensity between different epitope mapping trials and the results of an antigenicity plot, some spots belong to an epitope, even if they show low staining in this figure.

peptides revealed cross-reactivity with $\mathrm{fZP}$ antiserum in ELISA even though peptides P2, P4 and P5 failed to crossreact in the dot immunoassay. Results for P1 were hard to interpret because of its reduced solubility in aqueous solutions. A strong response was documented for P3 and P6 in both detection systems. For this reason, these two peptides were chosen for immunization and in vitro experiments.

\section{In vitro test for sperm binding and fertilization}

IVM was achieved in 426 of 551 (77.3\%) cultured eggs and expressed no significant differences between all experimental groups. Fertilization occurred in 85 of 173 matured eggs $(49.1 \%$, based upon formation of a male pronucleus or embryo cleavage) in the control.

\section{Experiment 1}

Pre-incubation of sperm with peptide P3 or P6 and following co-incubation with oocytes showed no significant influence on sperm binding, neither in in vitro-matured oocytes (mean number of sperm per egg for control: $22.3 \pm 3.7$, for P3 and P6 respectively $25.5 \pm 5.8$ and $20.7 \pm 4.0$; for P3 $P=0.418$, for P6 $P=0.418$ ) nor in denuded ones (control: $30.9 \pm 5.3, \mathrm{P} 3$ and P6 respectively $25.7 \pm 1.1$ and $30.7 \pm 1.2$; for $\mathrm{P} 3 \mathrm{P}=0.267$, for $\mathrm{P} 6$ $P=0.527$; Table 2). Also, no differences in fertilization rate were found (Table 3 ).

\section{Experiment 2}

The addition of rat anti-P3 antiserum to IVF culture medium led to a significant inhibition of sperm binding in matured oocytes compared with the control group
(P3 antiserum: $5.6 \pm 2.4$ sperm/egg, control: $13.2 \pm 4.1$ sperm/egg, $P=0.016<0.05)$. Sperm binding in denuded oocytes was reduced by $46.2 \%$ compared with the control group, but the difference was not significant (Table 4). An inhibitory effect of anti-P3 antiserum on fertilization rate (P3 antiserum: 40.7\%, control: $69.6 \%$, based on matured oocytes) was also detected. Inhibition of sperm binding or fertilization was not detected for the anti-P6 antiserum in either matured or denuded oocytes (Tables 4 and 5). Regarding this result, also an anti-fertile effect of anti-BSA antibodies in the antisera can be excluded. Both rat antisera contain a comparable level of antibodies against BSA assessed by dot immunoassay.

\section{Discussion}

Using a highly specific antibody against native ZP of domestic cats, we identified six immunogenic epitopes within the amino acid sequence of fZPB. However, only one of these six epitopes expressed an anti-fertile effect in vitro, when antibodies against the synthetic peptide were added to the fertilization medium.

Epitope mapping by the spot synthesis technique represents an easy method for epitope screening. However, further analysis of epitope-derived synthetic peptides indicates a quite differentiated immune reaction of the fZP antiserum, since only two of the six peptides reliably cross-reacted in the dot immunoassay and ELISA (Table 1). We suggest that the reason for the differentiated reaction is that only P3 and P6 represent linear epitopes, whereas the other sequences may belong to non-linear epitopes (Geysen et al. 1985, 1987). For instance, the synthetic peptide P1 was highly hydrophobic and the cross-reactivity therefore could not be verified using ELISA or dot 


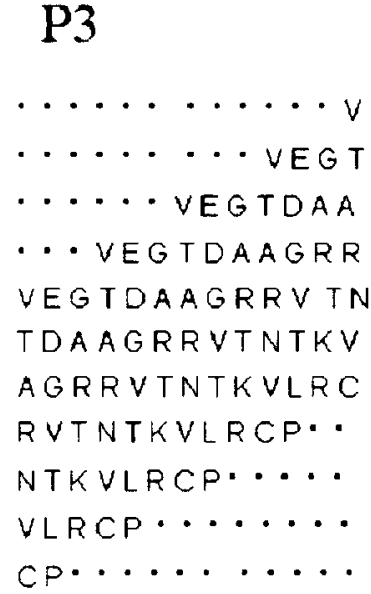

Sequences of overlapping peptides representing epitope 3

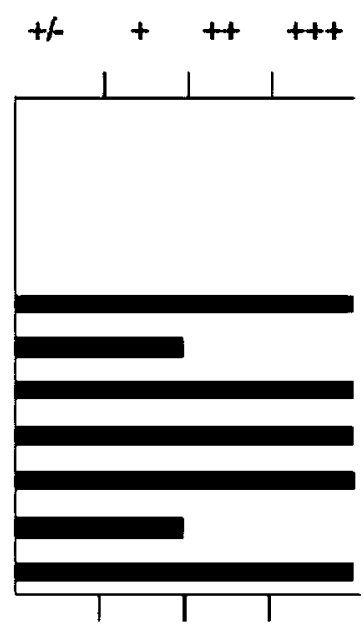

Immune reaction in dot-blot analysis

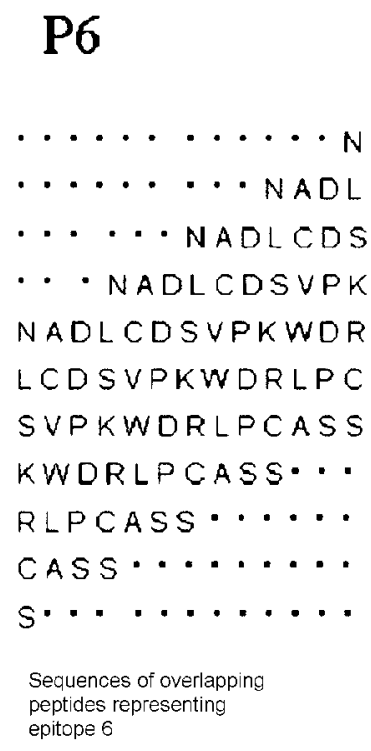

Figure 2 Epitope P3 and P6 - parts of the ZPB sequence representing peptide P3 and P6 respectively. Length of the bars indicates the strength of the immune reaction. The strength was determined by the darkness of the spots in the epitope mapping range from shades of gray to black.

immunoassay but its sequence had been recognized by the $\mathrm{fZP}$ antiserum in the epitope mapping. Thus, the presentation of this epitope within the native $Z P$ can only be assured by forming the three dimensional structure of ZP.

Since the epitopes were too small to be effective as vaccines, the peptides were coupled to a carrier protein to generate an immune reaction after inoculation. However, after repeated vaccination the antibody titers raised in rats were low. Nevertheless, the antiserum against peptide P3 (serum titer 1:5000) did suppress the fertilization of cat oocytes after being diluted to 1:10. For P6, we cannot

Table 1 Amino acid sequence of the six synthetic peptides derived from the identified epitopes and cross-reactivity with specific anti-fZP antiserum tested in dot immunoassay and ELISA.

\begin{tabular}{lccc}
\hline & & \multicolumn{2}{c}{$\begin{array}{c}\text { Cross-reactivity with } \\
\text { anti-fZP antiserum }\end{array}$} \\
\cline { 3 - 4 } Peptide & Amino acids of ZPB & Dot blot & ELISA* \\
\hline P1 & $314-338$ & $?$ & $?$ \\
P2 & $373-385$ & - & + \\
P3 & $130-149$ & + & ++ \\
P4 & $249-269$ & - & ++ \\
P5 & $141-159$ & - & ++ \\
P6 & $175-193$ & ++ & +++ \\
\hline
\end{tabular}

* Results of ELISA were quantified as difference of optical density (OD) of antiserum (dilution 1:10 000) compared with non-specific binding (NSB)

?, not evaluable; + , light reaction (light gray spot), difference of OD of antiserum from NSB is $0.1-0.3 ;++$, moderate reaction (dark gray spot), difference of OD of antiserum from NSB is $0.3-0.6 ;+++$, strong reaction (black spot) difference of OD of antiserum from NSB is $>0.6$; - , no reaction (no spot), difference of OD of antiserum from NSB is $<0.1$.

exclude a possible anti-fertile effect since the antibody titer was $<1: 5000$ and could not be properly verified. For immunization with native pZP in several wild and feral animals it was shown that a serum level of less than 1:800 was ineffective in suppression of fertility (Jewgenow et al. 2001). Presumably for synthetic peptides a more elevated titer is required to be effective. Due to our low titers, application of BSA as a carrier protein for further immunization studies should be reconsidered. Mahi-Brown (1996) tested different carrier proteins such as keyhole limpet hemocyanin $(\mathrm{KLH}), \mathrm{BSA}$, ovalbumin, tetanus toxoid and multiple antigen peptides. Although peptides conjugated to KLH elicited a high response in mice, a high titer in cynomolgus macaques (Macaca fascicularis) was restricted to antibodies against the carrier. The highest titers against the peptide were produced with tetanus toxoid as carrier. Apart from KLH (Miller et al. 1997, Shigeta et al. 2000), other authors have successfully applied diphtheria toxoid to boost the immunogenicity of their peptides (Kaul et al. 1996, Afzalpurkar et al. 1997, Shigeta et al. 2000).

Application of synthetic peptides derived from ZP glycoproteins for immunocontraception was first demonstrated by Millar et al. (1989) in mice. The 16-mer mouse ZP3 synthetic peptide was subsequently shown to possess T-cell epitopes and to induce inflammatory oophoritis in susceptible strains of mice (Rhim et al. 1992). Because of the established contraceptive success, subsequent studies continued to investigate the modified versions of the mouse ZP3 epitope or homologue sequences from other species (Lou \& Tung 1993, Gupta et al. 1994, Mahi-Brown \& Moran 1995, Miller et al. 1997, Paterson et al. 1999). Aitken et al. (1990) emphasized the importance of glycosylation of zona antigens for the immunogenicity and their contraceptive efficacy. Despite the lack 
Table 2 Binding of fresh epididymal sperm to fZP of in vitro-matured and nude oocytes. Before fertilization, cat sperm were pre-incubated with peptide P3 or P6 $(1 \mu \mathrm{g} / \mathrm{ml})$ for $1 \mathrm{~h}$; culture medium contained BSA $(6 \mathrm{mg} / \mathrm{ml})$.

\begin{tabular}{lrrr}
\hline Oocytes (no. of experiments) & Pre-incubation & Sperm cells/oocyte & Inhibition (\%) \\
\hline Matured oocytes $(7)$ & Control $(n=97)$ & $22.3 \pm 3.7$ & - \\
& P3 $(n=96)$ & $25.5 \pm 5.8$ & $-14.1 \pm 14.6 *$ \\
Nude Oocytes $(7)$ & P6 $(n=98)$ & $20.7 \pm 4.0$ & $7.4 \pm 8.6^{*}$ \\
& Control $(n=86)$ & $30.9 \pm 5.3$ & - \\
& P3 $(n=81)$ & $25.7 \pm 1.1$ & $16.9 \pm 4.2 *$ \\
P6 $(n=82)$ & $30.7 \pm 1.2$ & $0.7 \pm 1.6$ \\
\hline
\end{tabular}

* No significant difference from control.

Table 3 IVF of domestic cat oocytes with fresh epididymal sperm preincubated with peptide P3 and P6 $(1 \mu \mathrm{g} / \mathrm{ml})$.

\begin{tabular}{lccc}
\hline $\begin{array}{c}\text { Pre-incubation } \\
\text { (no. of oocytes) }\end{array}$ & $\begin{array}{c}\text { Maturation rate } \\
(n)\end{array}$ & $\begin{array}{c}\text { Fertilization rate } \\
(n)\end{array}$ & $\begin{array}{c}\text { Inhibition } \\
(\%)\end{array}$ \\
\hline Control $(97)$ & $79.4 \%(77)$ & $49.4 \%(38)$ & - \\
P3 (96) & $79.2 \%(76)$ & $43.4 \%(33)$ & $12.1 *$ \\
P6 (98) & $67.3 \%(66)$ & $57.6 \%(38)$ & $-*$ \\
\hline
\end{tabular}

* No significant difference from control.

of glycosylation as well as native tertiary protein structure, positive results of the aforementioned studies prompted us to concentrate on synthetic peptides.

The present study focuses on fZPB protein (Harris et al. 1994). We made this decision because $Z P B$ is the first $Z P$ gene that is expressed during oogenesis in cats (Jewgenow \& Fickel 1999) and because immunization against ZPB can lead to infertility (Martinez \& Harris 2000). Recombinant human ZPB was successfully used for contraception in cynomolgus monkeys and baboons. Govind et al. (2000) revealed a conserved B-cell epitope in the bonnet monkey (Macaca radiata) corresponding to amino acids 136-147. It overlaps with our peptide P6 in nine amino acids but only five of these were identical. The epitope showed cross-reactivity with monoclonal antibodies which were able to inhibit sperm binding significantly.

After immunocontraception with ZP-derived peptides, the fertility of animals can be affected by different mechanisms. The first possibility is affecting the sperm receptor. In this case, ZP peptides are able to react with sperm cells and reduce their fertilizing capacity. Since neither peptide
Table 5 IVF of domestic cat oocytes with fresh and cryopreserved epididymal sperm in the presence of $10 \%$ rat pre-immune serum (control), antisera raised against peptide P3 (P3 antiserum) and against peptide P6 (P6 antiserum). Fertilization rate was estimated according to the number of matured eggs.

\begin{tabular}{lccc}
\hline $\begin{array}{l}\text { Co-incubation } \\
\text { (no. of oocytes) }\end{array}$ & $\begin{array}{c}\text { Maturation rate } \\
(n)\end{array}$ & $\begin{array}{c}\text { Fertilization rate } \\
(\mathrm{n})\end{array}$ & $\begin{array}{c}\text { Inhibition } \\
(\%)\end{array}$ \\
\hline Control (65) & $70.8 \%(46)$ & $69.6 \%(32)$ & - \\
P3 antiserum (65) & $83.1 \%(54)$ & $40.7 \%(22)$ & $41.5 *$ \\
Control (85) & $75.3 \%(64)$ & $39.1 \%(25)$ & - \\
P6 antiserum (84) & $85.7 \%(72)$ & $52.8 \%(38)$ & - \\
\hline
\end{tabular}

* Significant difference from control (chi-square $=7.189)$ with $P=0.0073$.

P3 nor P6 inhibited the binding and fertilization of cat sperm in vitro, it is unlikely that they represent a sperm receptor. The second possibility to reduce the fertilization rate is to cover the surface of oocytes with antibodies, making sperm binding and penetration impossible (Sacco 1981). We suppose that the reduction of fertilization and sperm binding rate in the presence of anti-P3 antiserum in vitro is based on this mechanism (Tables 4 and 5). The last mechanism of infertility induction by vaccination with ZP peptides is T-cell induced autoimmune destruction of ovarian cells. We did not investigate whether our peptides are T-cell epitopes. Our peptides, however, were identified by rabbit antibodies. This indicates that at least in rabbits these peptides are B-cell epitopes. Although characterization of immune cell activation, either T- or B-cells, must be done in the target species - domestic cats - we would like to emphasize that application of IVF and the sperm

Table 4 Binding of fresh and cryopreserved epididymal sperm to fZP of in vitro-matured and nude oocytes. The fertilization medium contained normal rat serum (control, 10\%), antiserum raised against P3 (P3 antiserum, 10\%) or antiserum against P6 (P6 antiserum, $10 \%$ ).

\begin{tabular}{lccc}
\hline Oocytes (no. of experiments) & Co-incubation (no. of oocytes) & Sperm cells/oocyte & Inhibition (\%) \\
\hline Matured oocytes (5) & Control serum (96) & $14.6 \pm 3.4$ & - \\
& P3 antiserum (94) & $5.0 \pm 2.0$ & $65.8 \pm 13.8 *$ \\
Nude oocytes (4) & Control serum (140) & $22.5 \pm 7.5$ & - \\
Matured oocytes (6) & P3 antiserum (137) & $12.1 \pm 5.1$ & $46.2 \pm 25.7$ \\
Nude oocytes (5) & Control serum (85) & $12.9 \pm 5.9$ & - \\
& P6 antiserum (84) & $13.7 \pm 8.3$ & $-6.0 \pm 65.6$ \\
& Control serum (217) & $9.4 \pm 4.1$ & - \\
& P6 antiserum (208) & $6.6 \pm 1.7$ & $30.4 \pm 130.0$ \\
\hline
\end{tabular}

* Significant difference from control; $P=0.0159$. 
binding test is a valuable tool to examine the anti-fertile potential of relevant vaccines. The in vitro approach also allows reduction in the number of experimental animals. The interference of substances with sperm cells and oocytes during the fertilizing process can give important insights into the mechanism of successful contraception.

In conclusion, antibodies directed against one of the two identified antigenic determinants of fZPB inhibited sperm binding and fertilization in vitro and therefore showed promising results as a contraceptive. However, the specific immune response and anti-fertile properties of this synthetic vaccine have to be examined in vivo to verify the suitability of its components. Immunization studies in cats are currently under way.

\section{Acknowledgements}

We would like to thank Christiane Franz for excellent technical assistance and Dr Heribert Hofer for his thoughtful comments and improving the English. We are also very thankful to the staff of the Berlin animal shelter for providing the source material.

\section{References}

Afzalpurkar A, Shibahara H, Hasegawa A, Koyama K \& Gupta SK 1997 Immunoreactivity and in-vitro effect on human sperm-egg binding of antibodies against peptides corresponding to bonnet monkey zona pellucida-3 glycoproteins. Human Reproduction 12 2664-2670.

Aitken RJ, Paterson M, Braude P \& Thillai Koothan P 1990 Evaluation of glycosylated and deglycosylated porcine zona antigens for contraceptive efficacy in vivo and in vitro. In Gamete Interaction: Prospects for Immunocontraception, pp 293-312. Eds NJ Alexander, D Griffin, JM Spieler \& GMH Waites. New York: Wiley-Liss.

Asa CS, Porton I, Baker AM \& Plotka ED 1996 Contraception as a management tool for controlling surplus animals. In Wild Animals in Captivity, pp 451-467. Eds DG Kleimann, ME Allen \& KV Thompson. Lumpkin, Chicago, IL and London: University of Chicago Press.

Barber MR, Lee SM, Steffens WL, Ard M \& Fayrer-Hosken RA 2001 Immunolocalization of zona pellucida antigens in the ovarian follicle of dogs, cats, horses and elephants. Theriogenology $\mathbf{5 5}$ 1705-1717.

Foley JE, Foley P, Levy J \& Paik T 2002 Feral cat population dynamics: modeling the effect of trap, neuter, and release in feral cats in San Diego County. Proceedings of the 2002 International Symposium on Nonsurgical Methods for Pet Population Control, Pine Mountain, GA, USA. p 29.

Frank R 1992 Spot-synthesis: an easy technique for the positionally addressable, parallel chemical synthesis on a membrane support. Tetrahedron 48 9217-9232.

Freistedt P, Stojkovic M \& Wolf E 2001 Efficient in vitro production of cat embryos in modified synthetic oviduct fluid medium: effects of season and ovarian status. Biology of Reproduction 65 9-13.

Geysen HM, Barteling SJ \& Meloen RH 1985 Small peptides induce antibodies with a sequence and structural requirement for binding antigen comparable to antibodies raised against the native protein. PNAS 82 178-182.

Geysen HM, Rodda SJ, Mason TJ, Tribbick G \& Schoofs PG 1987 Strategies for epitope analysis using peptide synthesis. Journal of Immunological Methods 102 259-274.

Gorman SP, Levy JK, Hampton AL, Collante WR, Harris AL \& Brown RG 2002 Evaluation of a porcine zona pellucida vaccine for the immunocontraception of domestic kittens (Felis catus). Theriogenology 58 135-149.

Govind CK, Hasegawa A, Koyama K \& Gupta SK 2000 Delineation of a conserved $\mathrm{B}$ cell epitope on bonnet monkey (Macaca radiata) and human zona pellucida glycoprotein-B by monoclonal antibodies demonstrating inhibition of sperm-egg binding. Biology of Reproduction 62 67-75.

Gupta SK, Kaul R, Rajalakshmi S, Sahai P, Yurewicz EC \& Sacco AG 1994 Immunoreactivity with native zona pellucida of antibodies against a 19 amino acid synthetic peptide corresponding to human ZP3. Journal of Reproductive Immunology 27 241-247.

Harris JD, Hibler DW, Fontenot GK, Hsu KT, Yurewicz EC \& Sacco AG 1994 Cloning and characterization of zona pellucida genes and cDNAs from a variety of mammalian species: the ZPA, ZPB and ZPC gene families. DNA Sequence 4 361-393.

Hopp TP \& Woods KR 1981 Prediction of protein antigenic determinants from amino acid sequences. PNAS 78 3824-3828.

Ivanova M, Petrov M, Klissourska D \& Mollova M 1995 Contraceptive potential of porcine zona pellucida in cats. Theriogenology 43 969-981.

Jewgenow K \& Fickel J 1999 Sequential expression of zona pellucida protein genes during the oogenesis of domestic cats. Biology of Reproduction 50 522-526.

Jewgenow K, Rohleder M \& Wegner I 2000 Differences between antigenic determinants of pig and cat zona pellucida proteins. Journal of Reproduction and Fertility 119 15-23.

Jewgenow K, Göritz F, Hildebrandt TB, Rohleder M, Wegner I \& Kolter L 2001 Bestimmung des Antikörpertiters gegen SchweineZona-Pellucida bei Zootieren vor und nach Kontrazeption mit porcinen Zona pellucida (pZP) Proteinen. Der Zoologische Garten NF 3 1-14.

Kaul R, Afzalpurkar A \& Gupta SK 1996 Strategies for designing an immunocontraceptive vaccine based on zona pellucida synthetic peptides and recombinant antigen. Journal of Reproduction and Fertility Supplement 50 127-134.

Kirkpatrick JF, Calle PP, Kalk P, Kolter L, Zimmermann W, Goodrowe K et al. 1993 Immunocontraception in zoo animals: vaccinating against pregnancy. Proceedings of American Association of Zoo Veterinarians, Saint Louis, MO, USA. pp 290-292.

Kyrein HJ 1983 Der Radioimmunoassay für Steroidhormone-Grundlagen, Entwicklung und Anwendung radioimmunologischer Testverfahren Teil I + II. Zeitschrift für Lebensmitteluntersuchung und-forschung 177 415-438.

Lengwinat T \& Blottner S 1994 In vitro fertilization of follicular oocytes of domestic cats using fresh and crypreserved epididymal spermatozoa. Animal Reproduction Science 35 291-301.

Lou Y \& Tung KSK 1993 T cell peptide of a self protein elicits autoantibody to the protein antigen: implications for specificity and pathogenetic role of antibody in autoimmunity. Journal of Immunology 148 1495-1505.

Mahi-Brown CA 1996 Primate response to immunization with a homologous zona pellucida peptide. Journal of Reproduction and Fertility Supplement 50 165-174.

Mahi-Brown CA \& Moran F 1995 Response of cynomolgus macaques to immunization against a synthetic peptide from the human zona pellucida. Journal of Medical Primatology 24 258-270.

Mahi-Brown CA, Yanagimachi R, Nelson ML, Yanagimachi H \& Palumbo N 1988 Ovarian histopathology of bitches immunized with porcine zonae pellucidae. American Journal of Reproduction Immunology and Microbiology 18 94-103.

Martinez ML \& Harris JD 2000 Effectiveness of zona pellucida protein ZPB as an immunocontraceptive antigen. Journal of Reproduction and Fertility 120 19-32.

Millar SE, Chamow SM, Baur AW, Oliver C, Robey F \& Dean J 1989 Vaccination with a synthetic zona pellucida peptide produces long-term contraception in female mice. Science 246 935-938.

Miller LA, Johns BE, Elias DJ \& Crane KA 1997 Comparative efficacy of two immunocontraceptive vaccines. Vaccine 15 1858-1862. 
Paterson $M$, Wilson MR, Jennings $Z$ A, van Duin $M$ \& Aitken RJ 1999 Design and evaluation of a ZP3 peptide vaccine in a homologous primate model. Molecular Human Reproduction $\mathbf{5}$ 342-352.

Reineke U, Kramer A \& Schneider-Mergener J 1999 Antigen sequence- and library-based mapping of linear and discontinuous protein-protein interaction sites by spot synthesis. Current Topics in Microbiology and Immunology 243 23-36.

Rhim SH, Millar SE, Robey F, Luo A-M, Yule T, Allen P et al. 1992 Autoimmune disease of the ovary induced by a ZP3 peptide from the mouse zona pellucida. Journal of Clinical Investigation 89 $28-35$.

Sacco AG 1981 Immunocontraception: consideration of the zona pellucida as a target antigen. Obstetrics and Gynecology Annual 10 $1-26$.

Sacco AG, Yurewicz EC \& Subramanian MG 1989 Effect of varying dosages and adjuvants on antibody response in squirrel monkeys (Saimiri sciureus) immunized with the porcine zona pellucida $\mathrm{M}_{\mathrm{r}}=55000$ glycoprotein (ZP3). American Journal of Reproductive Immunology 21 1-8.
Sacco AG, Yurewicz EC, Subramanian MG, Liam YE \& Dukelow WR 1991 Immunological response and ovarian histology of squirrel monkeys (Saimiri sciureus) immunized with porcine zona pellucida ZP3 $\left(\mathrm{M}_{\mathrm{r}}=55000\right)$ macromolecules. American Journal of Primatology 24 15-28.

Shigeta M, Hasegawa A, Hamada Y \& Koyama K 2000 Analysis of B cell epitopes of a glycoprotein porcine zona pellucida (pZP1). Journal of Reproduction Immunology 47 159-168.

Skinner SM, Mills T, Kirchick HJ \& Dunbar BS 1984 Immunization with zona pellucida protein results in abnormal ovarian follicular differentiation and inhibition of gonadotropin-induced steroid secretion. Endocrinology 115 2418-2432.

Steeves TE \& Gardner DK 1999 Temporal and differential effects of amino acids on bovine embryo development in culture. Biology of Reproduction 61 731-740.

Received 6 October 2003

First decision 18 September 2003

Accepted 17 October 2003 